[Agr. Biol. Chem., Vol. 34, No. 1, p. 80 87, 1970]

\title{
Influence of Dietary Composition on the Capacity of Glucose Formation in Liver of Rats
}

\author{
By Hiroo SuzukI and Hidetsugu Fuwa \\ Laboratory of Nutritional Biochemistry, Department of Agricultural Chemistry, \\ Faculty of Agriculture, Nagoya University, Nagoya \\ Received June 12, 1969
}

\begin{abstract}
The influence of the levels of dietary carbohydrate, protein, and fat on the capacity of glucose formation in liver slices and on the activities of gluconeogenic and glycolytic enzymes in the liver of rats were investigated. Incorporation of radioactivity from pyruvate${ }^{3-14} \mathrm{C}$ into glucose by liver slices not only increased in carbohydrate deficient groups, but also was affected by fat content of diets. PEPCK, FDPase, and G6Pase of rat liver were affected by the levels of dietary carbohydrate. Moreover, PEPCK and FDPase were increased by increasing the protein content of diets and G6Pase was increased by increasing the fat content of diets. The ratios PEPCK/PK and G6Pase/GK were increased significantly by decreasing the carbohydrate content of diets, but the ratio FDPase/PFK did not show any significant change among dietary groups. From these experiments, it was concluded that the capacity of glucose formation in the liver of rats was changed by carbohydrate and fat content of diets and changes in gluconeogenic capacity with diets were correlated with changes in G6Pase activity.
\end{abstract}

Unless carbohydrate is continually ingested with food, the needs for glucose in the animal must be met by the degradation of the reserve polysaccharide of the body (glycogenolysis) and/or by the conversion of non-carbohydrate precursors to glucose (gluconeogenesis).

It has been shown that the sum of percent incorporation of ${ }^{14} \mathrm{C}$ from amino acid $-{ }^{14} \mathrm{C}$ or pyruvate $-{ }^{14} \mathrm{C}$ into blood glucose and liver glycogen was increased in rats fed a low carbohydrate diet high in protein ${ }^{1,2}$ or high in $\mathrm{fat}^{2 \prime}$ than in rats fed a high carbohydrate diet. It was also increased in fasted rats than in normally fed rats. ${ }^{3,41}$ Increased incorporation can be the consequence of either increased

1) T. Kimura and K. Ashida, Agr. Biol. Chem., 32, 1440 (1968).

2) B. Friedmann, K. H. Goodmann and S. Weinhouse, Federation Proc., 25, 347 (1966).

3) G. B. Nadkarin, B. Friedmann and S. Weinhouse, J. Biol. Chem., 235, 420 (1960).

4) B. Friedmann, E. H. Goodmann and S. Weinhouse, ibid., 240, 3729 (1965). glucose synthesis, or decreased utilization of glucose, or both. Evidences considered to support all these possibilities have accumulated by studies utilizing tissue slices ${ }^{5}$ and measuring activities of gluconeogenic and glycolytic enzymes of the liver and kidney cortex ${ }^{6}$ which are the main site of gluconeogenesis. Further, in recent studies on diabetic animals and cortisone treated normal animals, increased formation of glucose has been shown in vivo ${ }^{71}$ and in vitro. ${ }^{8 \sim 10)}$

From the facts, it is assumed that the capacity of glucose formation in rat liver depends

5) H. Krebs, Proc. Roy. Soc. (London), 159 (B), 545 (1964).

6) G. Weber, Advances in Enzyme Regulation, 1, 13 (1964).

7) B. R. Landau, R. Mahlev, J. Ashmore and D. Elwege, Endocrinology, 70, 47 (1962).

8) G. Weber and A. Cantero, Science, 120, 851 (1954).

9) J. Ashmore, A. B. Hasting and F. B. Nesbet, Proc. Natl. Acad. Sci., 40, 673 (1954).

10) W. M. Fitch and I. L. Chaikoff, Biochim. Biophys. Acta, 57, 588 (1962). 
upon the levels of carbohydrate in diets. Therefore, the purpose of this study is to investigate the situation in more detail by tissue slices. Moreover, since it is possible to deduce the capacity of glucose formation in tissues from the activity of gluconeogenic enzyme or the ratio of gluconeogenic enzyme activity to glycolytic enzyme activity, the influence of the levels of dietary carbohydrate on the activities of gluconeogenic and glycolytic enzymes was investigated.

\section{METHODS AND MATERIALS}

Animals and Diets. Donryu strain rats were purchased from Nippon Rat Co., Urawa. Unless otherwise stated, all animals were females, about 100 170

TABle I. Composition of DieT $T^{a}-1$

\begin{tabular}{lccc}
\hline & $\begin{array}{c}\text { 25 P-S } \\
\text { High } \\
\text { carbohydrate } \\
\text { diet }(\mathrm{g})\end{array}$ & $\begin{array}{c}\text { 25 P-F } \\
\text { High } \\
\text { protein diet } \\
(\mathrm{g})\end{array}$ & $\begin{array}{c}\text { 75P-S } \\
\text { High } \\
\text { fat diet } \\
(\mathrm{g})\end{array}$ \\
\hline Casein & 250 & 750 & 250 \\
$\alpha$-Starch & 640 & 123 & - \\
Corn oil (or Lard) & 50 & 50 & 306 \\
Mineral mixture $\mathrm{B}^{b)}$ & 50 & 50 & 50 \\
Vitamin mixture $^{b)}$ & 8.5 & 25.5 & 8.5 \\
Choline chloride & 1.5 & 1.5 & 1.5 \\
\hline
\end{tabular}

$\mathrm{g}$ in body weight. The animals were housed in individual cages placed in a temperature regulated room at about $25^{\circ} \mathrm{C}$ and $12-\mathrm{hr}$ per day of darkness and light and were weighed daily. Diets and water were available ad libitum unless stated otherwise. Diets were prepared by substituting; (a) fat for carbohydrate at constant protein, (b) protein for fat at constant carbohydrate. The composition of diets are shown the Tables I and II. All the test diets contain the same amounts of salts per 100 calculated calories. The amounts of the mixture of vitamins used were proportional to the levels of protein in diets, namely, $8.5 \mathrm{~g}$ for $250 \mathrm{~g}$ of casein and $25.5 \mathrm{~g}$ for $750 \mathrm{~g}$ of casein. The stock diet was pellets delivered from Central Laboratories for Experimental Animals, Tokyo.

Materials. Glucose 6-phosphate dehydrogenase (from yeast), aldolase (from rabbit muscle), ATP- $\mathrm{Na}_{2} \mathrm{H}_{2}$ $3 \mathrm{H}_{2} \mathrm{O}$, ADP-Na $a_{3}$, ITP-Ba, FDP-Na ${ }_{3} \mathrm{H}$, F6P-Ba, G6P$\mathrm{Na}_{2}, \quad \mathrm{PEP}-\mathrm{Na}-\mathrm{H}_{2} \mathrm{O}, \mathrm{OAA}$ and $\mathrm{NADP}-\mathrm{NaH}_{2}$ were purchased from C.F. Boebringer \& Soehne $\mathrm{GmbH}$, Manheim. Sodium pyruvate-3-14 $\mathrm{C}$ was purchased from Radiochemical Centre, Amersham, Buckinghamshire, England. Chemicals were used without further purification.

Preparation of liver slices and assay of glucose formation from pyruvate-3-14C. Slice were cut from livers by sliding a razor blade along the surface of a glass slide with a $0.3 \mathrm{~mm}$ deep groove which was pressed on to the liver samples. Liver slices $(100 \mathrm{mg})$ were transferred to vessels $(25 \mathrm{ml}$ vials fitted with rubber

TABLE II. Composition of DIETS $\left.{ }^{a}\right)-2$

\begin{tabular}{lcccccc}
\hline & $\begin{array}{c}75 \mathrm{P}-\mathrm{F} \\
(\mathrm{g})\end{array}$ & $\begin{array}{c}50 \mathrm{P}-\mathrm{F} \\
(\mathrm{g})\end{array}$ & $\begin{array}{c}25 \mathrm{P}-\mathrm{F} \\
(\mathrm{g})\end{array}$ & $\begin{array}{c}12 \text { S-P } \\
(\mathrm{g})\end{array}$ & $\begin{array}{c}35 \mathrm{~S}-\mathrm{P} \\
(\mathrm{g})\end{array}$ & $\begin{array}{c}63 \text { S-P } \\
(\mathrm{g})\end{array}$ \\
\hline Casein & 750 & 500 & 250 & 250 & 250 & 250 \\
$\alpha$-Starch & - & - & - & 123 & 358 & 640 \\
Lard $c)$ & 99 & 203 & 306 & 257 & 163 & 50 \\
Mineral mixture B & 50 & 50 & 50 & 50 & 50 & 50 \\
Vitamin mixture & 25.5 & 17 & 8.5 & 8.5 & 8.5 & 8.5 \\
Choline chloride & 1.5 & 1.5 & 1.5 & 1.5 & 1.5 & 1.5 \\
\hline
\end{tabular}

a) Diets were supplemented further with 6000 IU of vitamin A, 600 IU of vitamin D and $100 \mathrm{mg}$ of vitamin $\mathrm{E}$ per $\mathrm{kg}$ of diet. In order to prepare diets isocaloric per $\mathrm{g}$ of diet, cellulose powder was used.

b) A. E. Harper, J. Nutrition, 68, 405 (1959). See reference 32).

c) Butter was used as dietary fat instead of lard in Expt. 2. 
stoppers and hanging glass center wells) containing $2.5 \mathrm{ml}$ of a high potassium medium $\left.{ }^{11}\right)\left(40 \mathrm{~mm} \mathrm{KHCO}_{3}\right.$, $10 \mathrm{~mm} \mathrm{KGl}, 20 \mathrm{mM} \mathrm{MgCl}_{2}, 10 \mathrm{mM} \mathrm{CaCl}_{2}$, and $60 \mathrm{~mm}$ potassium pyruvate containing $1 \mu \mathrm{Ci}$ of sodium pyruvate-3-14 $\mathrm{C}, \mathrm{pH} 7.4$ ) and incubated for $60 \mathrm{~min}$ at $37^{\circ} \mathrm{C}$ in an atmosphere of $\mathrm{O}_{2}-\mathrm{CO}_{2}(95: 5)$ with shaking. At the end of the incubation, $0.2 \mathrm{ml}$ of the mixture of ethanol amine and ethylene-glycol monomethylether $(1: 2 \mathrm{v} / \mathrm{v})$ was introduced through the rubber stopper with a syringe and hypodermic needle on to the filter paper in the center well. To ensure complete liberation of $\mathrm{CO}_{2}, 0.5 \mathrm{ml}$ of $0.2 \mathrm{~N} \mathrm{H}_{2} \mathrm{SO}_{4}$ was injected into the medium and shaking was continued for $30 \mathrm{~min}$. The filter paper containing the $\mathrm{CO}_{2}$ was allowed to dry, flattened to the bottom of a vial, and $10 \mathrm{ml}$ of dioxane scintillation solution $(4 \mathrm{~g}$ of $\mathrm{PPO}, 0.2 \mathrm{~g}$ of POPOP, $60 \mathrm{~g}$ of naphthalene, $20 \mathrm{ml}$ of ethylenglycol, $100 \mathrm{ml}$ of methanol and dioxane to one liter) was added. Reaction medium was transferred to a centrifuge tube and centrifuged at $2500 \mathrm{rpm}$ for $10 \mathrm{~min}$. One $\mathrm{ml}$ of supernatant was passed through an Amberlite $\mathrm{MB}-2$ column $(0.8 \times 15 \mathrm{~cm})$. The column was eluted with water and the first $15 \mathrm{ml}$ of eluates was collected. An aliquot of purified eluate was used for determination of glucose-14 $\mathrm{C}$. Tissue slices were $\mathrm{di}$ gested with $2 \mathrm{ml}$ of $30 \% \mathrm{KOH}$ in boiling water for $40 \mathrm{~min}$, and glycogen was precipitated by the addition of $5 \mathrm{ml}$ of ethanol and purified according to Hassid et al. ${ }^{12}$ All samples were counted in a Packard TriCarb 314 EX type liquid scintillation spectrometer. Medium glucose and liver glycogen were determined by glucose-oxidase method and phenol-sulfuric acid method, respectively.

The results were expressed as $\mu$ moles of substrate converted into glucose per $100 \mathrm{~g}$ of body weight. In all experiments, the incorporation rate or ${ }^{14} \mathrm{C}$ into glucose, liver glycogen, and $\mathrm{CO}_{2}$ was expressed as counts per minute per $100 \mathrm{~g}$ of body weight. The incorporation of ${ }^{14} \mathrm{C}$ continued at a roughly linear rate throughout the incubation period.

Preparation of enzyme extracts and assay of enzyme activities. Rats were killed by blows on the head and allowed to bleed freely by decapitation before excision of tissue. The liver was quickly removed, cooled on ice, weighed, cut into small pieces and homogenized in a Potter-Elvehjem type glass homo-

11) F, J. Ballard and I. T. Oliver, Biochim. Biophys. Acta, 71, 578 (1963).

12) W. Z. Hassid and S. Abraham, "Methods in Enzymology," Vol. III ed, by S. P. Colowick and N. O. Kaplan, 1957, p. 35. genizer with a Teflon pestle.

PEPCK was assayed by a modification of the method of Nordlie et al.131 The assay was based on the measurement of PEP formed during incubation of the enzyme with saturating levels of OAA and ITP. PEP was cleaved with mercuric ion and the liberated $P_{1}$ was estimated by the method of P. S. Chen et al.14) One $g$ of rat liver was homogenized in 4 volumes of ice cold $0.25 \mathrm{M}$ sucrose and the homogenate was centrifuged at $20,000 \times g$ for $90 \mathrm{~min}$ at $0^{\circ} \mathrm{C}$. The supernatant fraction was used for the enzyme assay. PEPCK activity in the supernatant was stable for at least one week when stored in the frozen state at about $-15^{\circ} \mathrm{C}$. Inorganic phosphate derived from the enzyme solution (endogenous) and from reagents were determined under the condition of the enzyme assay without treatment of $\mathrm{HgCl}_{2}$.

PK was assayed by the method of Tanaka et al. ${ }^{15}$ which was based on the measurement of pyruvic acid formed during incubation of the enzyme with saturating levels of PEP and ADP. The red color of 2,4dinitrophenylhydrazone of pyruvic acid in the alcoholic alkaline solution was estimated at $530 \mathrm{~m} \mu$. The liver was homogenized with 3 volumes of $0.04 \mathrm{M} \mathrm{KCl}$ solution and the homogenate was centrifuged at 20,000 $\times g$ for $90 \mathrm{~min}$ at $0^{\circ} \mathrm{C}$. The supernatant was diluted with 10 volumes of water and used for the enzyme assay. PK activity was stable for several weeks in the frozen state. Blank assay was performed using water instead of the substrate.

G6Pase assay was performed by a slight modification of the method of Fitch et al.16) which was based on the measurement of $P_{1}$ formed during incubation of the enzyme with saturating levels of G6P. $P_{1}$ was determined colorimetrically by a modification of the method of Furchgette et al.17) The homogenates were prepared by the same procedure as the PEPCK assay and filtered through two layers of gauze and stored in a deep freezer at about $-15^{\circ} \mathrm{C}$. Under these conditions, the enzyme activity was stable for several weeks. Frozen homogenates were thawed and aliquots of these homogenates were supplemented with neutral

13) R.C. Nordlie, F.E. Vanicchic and D.D. Holten, Biochim. Biophys. Acta, 97, 216 (1965).

14) P. S. Chen, Jr., T.Y. Toribara and H. Warner, Anal. Chem., 28, 1756 (1956).

15) T. Tanaka, Y. Harano and H. Morimura, Biochem, Biophys. Res. Commns., 21, 55 (1965).

16) W. M. Fitch, R. Hill and I. L. Chaikoff, $J$. Biol. Chem., 234, 1045 (1959).

17) R. E. Furchgette and T. deGubareff, ibid., 223, 377 (1956). 
TABLE III. ENZYME ASSAYS

\begin{tabular}{|c|c|c|c|c|}
\hline Enzyme & Assay medium & $\begin{array}{l}\text { Volume of } \\
\text { reaction mix- } \\
\text { ture (ml) }\end{array}$ & $\begin{array}{l}\text { Products } \\
\text { determined }\end{array}$ & References \\
\hline PEPCK & $\begin{array}{l}\text { OAA, } 3.35 \mu \text { moles; GSH, } 0.80 \mu \text { mole; ITP, } 4.50 \\
\mu \text { moles; MgSO } 41.2 \mu \text { moles; NaF, } 10 \mu \text { moles; } \\
\text { Tris-HCl, } 73.0 \mu \text { moles; pH } 8.0\end{array}$ & 0.65 & $\mathrm{HgCl}_{2}$-labile $\mathrm{P}_{\mathrm{j}}$ & 13) \\
\hline PK & $\begin{array}{l}\mathrm{MgSO}_{4}, 5 \mu \text { moles; } \mathrm{KCl}, 100 \mu \text { moles; } \mathrm{ADP}, 2 \mu- \\
\text { moles; PEP, } 2 \mu \text { moles; } 1.0 \text { Tris-HCl, } 50 \mu \text { moles; } \\
\text { pH 7.5 }\end{array}$ & 1.0 & Pyruvic acid & 15) \\
\hline G6Pase & G6P, $20 \mu$ moles; maleatc-NaOH, $20 \mu$ moles; pH 6.8 & 1.0 & $P_{1}$ & 16) \\
\hline $\mathrm{HK}(\mathrm{GK})$ & $\begin{array}{l}\text { ATP, } 9 \mu \text { moles; NADP, } 2.25 \mu \text { moles; } \mathrm{MgCl}_{2}, 22.5 \\
\mu \text { moles; glucose, } 300 \mu \text { moles; G6P dehydrogenase, } \\
0.84 \text { unit (International Unit); Tris-HCl, } 132 \mu- \\
\text { moles; pH } 7.5\end{array}$ & 3.0 & NADPH & 18) \\
\hline FDPase & $\begin{array}{l}\text { FDP, } 0.5 \mu \text { moles; cysteine, } 100 \mu \text { moles; } \mathrm{MgSO}_{4} \text {, } \\
50 \mu \text { moles; Tris-HCl, } 250 \mu \text { moles; pH } 7.5\end{array}$ & 5.0 & $P_{i}$ & 19) \\
\hline PFK & $\begin{array}{l}\text { ATP, } 2 \mu \text { moles, hydrazine, } 2 \mu \text { moles; F6P, } 55 \mu \text { - } \\
\text { moles; aldolase, } 1 \mu \mathrm{g} \text {; Tris-HCl, } 50 \mu \text { moles; pH } 7.4\end{array}$ & 1.0 & Alkaline-labile $P_{i}$ & 20) \\
\hline
\end{tabular}

sodium deoxycholate solution (to a final concentration of $0.2 \%, w / v)$ prior to use for the assay of G6Pase.

Glucokinase assay was \& modification of the method of Sharma et al. ${ }^{18}$. The method was based on the measurement of the rate of production of NADPH at $340 \mathrm{~m} \mu$ in the presence of saturating levels of glucose, ATP, NADP, and an excess of G6P dehydrogenase. One $g$ of rat liver was homogenized with 2 volumes of $0.15 \mathrm{M} \mathrm{KCl}$ solution containing $5 \mathrm{mM} \mathrm{MgCl}_{2}, 5 \mathrm{mM}$

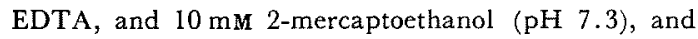
the homogenate was centrifuged at $20,000 \times g$ for 90 min at $0^{\circ} \mathrm{C}$. The supernatant fraction was dialyzed against 500 volumes of the buffer solution used for homogenization at $4^{\circ} \mathrm{C}$ for $150 \mathrm{~min}$. Dialysate was diluted to 2 -folds with water and used immediately for the enzyme assay because the enzyme activity was unstable. As the molar coefficient of absorbancy of $\mathrm{NADPH}$ at $340 \mathrm{~m} \mu$, the value $6.2 \times 10 \mathrm{~cm}^{2} \mathrm{~mole}^{-1}$ was used for calculation of the enzyme unit.

FDPase was assayed by the method of Taketa and Pogell19] with a slight modification. One $g$ of rat liver was homogenized in 4 volumes of ice cold 0.154 $\mathrm{M} \mathrm{KCl}$ solution and the homogenate was centrifuged at $20,000 \times g$ for $90 \mathrm{~min}$ at $0^{\circ} \mathrm{C}$. The supernatant was diluted to 50-folds with ice cold water prior to use for the enzyme assay. The determination of liberated inorganic phosphate was carried out by the

18) C. Sharma, R. Manjeshwar and S. Weinhouse, J. Biol. Chem., 238, 3840 (1963).

19) C. A. Taketa and R. M. Pogell, ibid., 240, 651 (1965). method of Chen et al.14) Enzyme activity was stable for at least two weeks in a deep freezer at about $-15^{\circ} \mathrm{C}$.

PFK assay was performed by a modification of the mothod of Weber et al.201 Triose phosphate formed from FDP by the action of aldolase was measured by the procedure of Sibley and Lehninger. ${ }^{211}$ Namely, triose phosphate trapped with hydrazine was hydrolyzed by sodium hydroxide and alkali-labile phosphate was determined by the method of Chen et al.14 Blank assay was performed using water instead of the substrate. One $g$ of rat liver was homogenized with 3 volumes of $20 \mathrm{mM}$ Tris- $\mathrm{HCl}$ buffer solution containing $5 \mathrm{mM} \mathrm{MgSO}_{4}$ and $0.1 \mathrm{mM}$ EDTA ( $\mathrm{pH} 8.0$ ) and the homogenate was centrifuged at $20,000 \times g$ for $90 \mathrm{~min}$ at $0^{\circ} \mathrm{C}$. The supernatant was used for the enzyme assay.

All enzyme assays were performed under conditions in which the amount of product formed was proportional to enzyme concentration and to incubation time, and conditions of enzyme assay were summarized in Table III.

One unit of enzyme activity was difined as the amount required to form one $u$ mole of product per minute under the assay condition, and the activities of enzymes were expressed as units of enzyme per $100 \mathrm{~g}$ of body weight.

20) G. Weber and R. L. Singhal, Life Science, 4, 1993 (1965).

21) J. A. Sibley and A. L. Lehninger, J. Biol. Chem., 177, 859 (1949). 


\section{Plan of experiments.}

Experiment 1. In order to determine the influence of a high carbohydrate, a high fat, and a high protein diet on the capacity of glucose formation in liver slices and on the activities of gluconeogenic and glycolytic enzymes in the liver, rats were maintained on the stock diet for at least two days since arrival, devided into three groups of five animals and fed 25 P-S (high carbohydrate diet), 25 P-F (high fat diet), or 75 P-S (high protein diet), respectively, for two weeks.

Experiment 2. Rat were maintained on the stock diet for two days, divided into four groups of six animals, and fed 75 P-F, 25 P-F, 35 S-P, or 63 S-P, respectively, or divided into six groups of five animals and fed 75 P-F, 50 P-F, 25 P-F, 12 S-P, 35 S-P, or $63 \mathrm{~S}-\mathrm{P}$, respectively, for two weeks. In order to change the level of carbohydrate in diets, 75 P-F, 50 P-F and 25 P-F diets were prepared by isocaloric substitution of calories from protein for calories from fat at constant very low carbohydrate and 25 P-F, 12 S-P, 35 S-P and 63 S-P diets were prepared by isocaloric substitution pyruvate- $3-{ }^{14} \mathrm{C}$ into medium glucose increased in rats fed the high fat diet, but a slight increase was observed in the high protein group. Respiratory ${ }^{14} \mathrm{CO}_{2}$ showed a significant increase in rats fed the high fat diet, but the incorporation of radioactivity was less than $1 / 50$ of that into glucose, and, moreover, the incorporation of ${ }^{14} \mathrm{C}$ into liver glycogen was negligible. Amounts of glucose formed did not change among test groups (Table IV). Although increased incorporation of ${ }^{14} \mathrm{C}$ from pyruvate- $-3-{ }^{14} \mathrm{C}$ into glucose was observed in rats fed low carbohydrate diets, the rates of incorporation were constant when the carbohydrate content was above $35 \%$ of diet (Table V). Thus, the higher response to low content of carbohydrate and the lower response to high content of protein in diets were indicated in experiments 1 and 2.

Recently, Friedmann et al. ${ }^{21}$ showed that the recovery per cent of ${ }^{14} \mathrm{C}$ from pyruvate-3${ }^{14} \mathrm{C}$ into blood glucose was increased in rats

Table IV. Influence of a High Carbohydrate Diet, a High Protein Diet, and a High Fat Diet on Incorporation of ${ }^{14} \mathrm{C}$ From Pyruvate-3-14C INTO Glucose, GLYCOGEN, AND $\mathrm{CO}_{2}$ BY LIVER SLICES OF RATS

\begin{tabular}{|c|c|c|c|c|c|}
\hline \multirow[b]{2}{*}{ Diet } & \multirow{2}{*}{$\begin{array}{c}\mathrm{CO}_{2} \\
\mathrm{cpm} \times 10^{-4}\end{array}$} & \multicolumn{2}{|l|}{ Glycogen } & \multicolumn{2}{|c|}{ Glucose } \\
\hline & & $\begin{array}{c}\text { Amounts } \\
\mathrm{mg} / 100 \mathrm{~g} \text { of body } \\
\text { weight }\end{array}$ & $\begin{array}{l}\text { Total } \\
\text { counts }\end{array}$ & $\begin{array}{l}\text { Amounts } \\
\mathrm{mg} / \mathrm{l00} \mathrm{g} \text { of body } \\
\text { weight }\end{array}$ & $\begin{array}{c}\text { Total counts } \\
\mathrm{cpm} \times 10^{-6} / 100 \mathrm{~g} \text { of } \\
\text { body weight }\end{array}$ \\
\hline $\begin{array}{l}\text { High carbohydrate } \\
\text { diet }\end{array}$ & $\begin{array}{c}6.11 a) \\
(5.88,6.33)\end{array}$ & $\begin{array}{c}77.3 \\
(58.1,96.5)\end{array}$ & $-b)$ & $\begin{array}{c}97.2 \\
(83.3,111)\end{array}$ & $\begin{array}{c}4.84 \\
(4.24,5.40)\end{array}$ \\
\hline $\begin{array}{l}\text { High protein } \\
\text { diet }\end{array}$ & $\begin{array}{c}8.98 \\
(7.35,10.6)\end{array}$ & $\begin{array}{c}30.0 \\
(24.9,35.4)\end{array}$ & - & $(94.3,114)$ & $\begin{array}{c}5.31 \\
(5.18,5.34)\end{array}$ \\
\hline High fat diet & $\begin{array}{c}12.0 \\
(11.9,12.3)\end{array}$ & $\begin{array}{c}29.0 \\
(19.1 \cdot 38.8)\end{array}$ & - & $\begin{array}{c}91.4 \\
(70.8,112)\end{array}$ & $\begin{array}{c}6.94 \\
(6.18,7.69)\end{array}$ \\
\hline
\end{tabular}

a) Mean for two animals. Individual value is indicated in parentheses.

b) Counts of glycogen ${ }^{14} \mathrm{C}$ was negligible in this study.

of calories from fat for calories from carbohydrate at constant protein. Caloric intake of each animal was restricted to about $40 \mathrm{cal}$ per $100 \mathrm{~g}$ of body weight per day.

\section{RESULTS AND DISCUSSION}

As shown in Table IV, incorporation of fed a high fat and a high protein diet, and the higher rate of incorporation was observed in the fat-fed group than that of the proteinfed group. Our experimental results by liver slices agree closely with those of in vivo study

22) B. Friedmann, E. H. Goodmann and S. Weinhouse, $J$. Biol. Chem., 242, 3620 (1967). 
Table V. INFluence of Dietary Garbohydrate, Protein, and FAT on InCorporation of ${ }^{14} \mathrm{C}$ FRom PyruVate-3-14 C InTO Glucose by LIVER SLICES OF RATS

\begin{tabular}{|c|c|c|c|c|}
\hline & \multicolumn{4}{|c|}{ Diet } \\
\hline & 75 P-F & $25 \mathrm{P}-\mathrm{F}$ & $35 \mathrm{~S}-\mathrm{P}$ & $63 \mathrm{~S}-\mathrm{P}$ \\
\hline Number of animals & 4 & 6 & 5 & 6 \\
\hline $\begin{array}{l}\text { Amounts of glucose } \\
\mathrm{mg} / 100 \mathrm{~g} \text { of body } \\
\text { weight }\end{array}$ & $118 \pm 30^{a}$ & $123 \pm 33$ & $125 \pm 32$ & $117 \pm 23$ \\
\hline $\begin{array}{l}\text { Total counts of } \\
\text { glucose-14 } \mathrm{C} \text { cpm } \times \\
10^{-6} / 100 \mathrm{~g} \text { of body } \\
\text { weight }\end{array}$ & $1.1 \pm 1.0$ & $2.0 \pm 2.3$ & $8.3 \pm 1.7$ & $8.9 \pm 2.0$ \\
\hline Carbohydrate cal & - & - & 35.0 & 62.5 \\
\hline Fat cal $\%$ & 24.0 & 74.6 & 39.7 & 12.5 \\
\hline Protein cal $\%$ & 73.2 & 24.4 & 24.4 & 24.4 \\
\hline
\end{tabular}

a) Mean \pm standard deviation
TABLE VI. INFLUENCE OF a High CaRbohydrate Diet, a High Protein Diet, and a High Fat Diet on THE ACtivities of GLUCONEOGENIC AND GLYCOLYTIC ENZYMES IN THE LIVER OF RATS

$\begin{array}{llll}\text { Enzyme } & \begin{array}{c}\text { High } \\ \text { carbohydrate } \\ \text { diet }\end{array} & \begin{array}{c}\text { High } \\ \text { protein } \\ \text { diet }\end{array} & \text { High } \\ \text { fat diet }\end{array}$

Table ViI. Influence of Dietary Carbohydrate, Protein, and Fat on the Activities of GLUCONEOGENIC AND GLYCOLYTIC ENZYMES IN THE LIVER OF RATS

\begin{tabular}{|c|c|c|c|c|c|c|}
\hline \multirow{2}{*}{ Enzyme } & \multicolumn{6}{|c|}{ Diet } \\
\hline & 75 P-F & $50 \mathrm{P}-\mathrm{F}$ & 25 P-F & $12 \mathrm{~S}-\mathrm{P}$ & $35 \mathrm{~S}-\mathrm{P}$ & 63 S-P \\
\hline G6Pase (A) & $90.7 \pm 15 a)$ & $105 \pm 8.7$ & $118 \pm 16$ & $92.5 \pm 13$ & $82.2 \pm 13$ & $78.3 \pm 6.7$ \\
\hline GK (B) & $2.54 \pm 0.2$ & $2.02 \pm 0.4$ & $1.70 \pm 0.2$ & $2.34 \pm 0.3$ & $3.64 \pm 0.7$ & $5.35 \pm 0.5$ \\
\hline (A) $/$ (B) & $36.0 \pm 7.2$ & $54.6 \pm 15$ & $74.4 \pm 9.2$ & $40.6 \pm 8.6$ & $23.0 \pm 4.8$ & $14.8 \pm 2.2$ \\
\hline FDPase (C) & $92.1 \pm 4.4$ & $92.4 \pm 6.3$ & $83.6 \pm 4.3$ & $80.3 \pm 4.3$ & $75.1 \pm 3.5$ & $73.3 \pm 3.3$ \\
\hline PFK (D) & $10.7 \pm 1.9$ & $11.1 \pm 1.9$ & $10.5 \pm 0.6$ & $9.25 \pm 1.0$ & $9.43 \pm 1.3$ & $8.45 \pm 0.7$ \\
\hline$(\mathrm{C}) /(\mathrm{D})$ & $8.84 \pm 1.4$ & $8.33 \pm 0.9$ & $7.97 \pm 0.7$ & $8.74 \pm 0.7$ & $8.05 \pm 0.8$ & $8.71 \pm 0.7$ \\
\hline PEPCK (E) & $60.7 \pm 4.0$ & $53.2 \pm 2.9$ & $42.3 \pm 3.5$ & $37.1 \pm 5.4$ & $28.1 \pm 5.2$ & $22.1 \pm 3.8$ \\
\hline $\mathrm{PK}(\mathrm{F})$ & $273 \pm 22$ & $251 \pm 8.7$ & $254 \pm 17$ & $285 \pm 5.6$ & $291 \pm 20$ & $398 \pm 75$ \\
\hline$(\mathrm{E}) /(\mathrm{F}) \times 100$ & $22.2 \pm 2.2$ & $21.8 \pm 1.7$ & $15.9 \pm 0.8$ & $13.0 \pm 2.4$ & $8.38 \pm 1.7$ & $6.18 \pm 0.3$ \\
\hline Carbohydrate cal $\%$ & - & - & - & 12.0 & 35.0 & 62.5 \\
\hline Protein cal $\%$ & 73.2 & 48.8 & 24.4 & 24.4 & 24.4 & 24.4 \\
\hline Fat cal $\%$ & 24.0 & 49.4 & 74.6 & 62.6 & 39.7 & 12.5 \\
\hline
\end{tabular}

a) Mean \pm standard deviation for five animals

of Friedmann et al. Thus, it is suggested that the hepatic gluconeogenesis play an important role on the homeostatic control of blood glucose at least under the condition of feeding of low carbohydrate diets high in fat.

23) G. Weber, S.K. Srivastava and R.L. Singhal, J. Biol. Chem., 240, 750 (1965).

24) A. E. Harper and F. G. Young, Biochem. J., 71, $696(1959)$.

25) S. R. Wagle and J. Ashmore, Biochim. Biophys.
It is known that rats fed low carbohydrate diets have the higher activities of hepatic gluconeogenic enzymes than those of rats fed high carbohydrate, ${ }^{23-27}$ and the activities of some hepatic glycolytic enzymes of rats fed Acta, 97, 142 (1965).

26) S. R. Wagle and J. Ashmore, J. Biol. Chem., 239, 1289 (1964).

27) J. W. Young and H. A. Lardy, Biochemistry, 3, 1687 (1964). 
low carbohydrate diets are lower than those of rats fed high carbohydrate diets. ${ }^{28-301}$ Thus, influences of dietary composition on the activities of gluconeogenic and glycolytic enzymes in the liver of rats were investigated and the results are shown in Tables VI and VII.

The activities of PEPCK of two groups fed low carbohydrate diets were higher than those of the high carbohydrate group, moreover, the activity of the high protein group was higher than that of the high fat group. On the other hand, the activities of PK of rats fed the high protein diet tended to be lower than that of the high carbohydrate group, though there was no statistically significant difference. The high fat group showed about $50 \%$ decrease in the activity as compared with that of the high carbohydrate group. PEPCK activity increased progressively in response to the progressive decrease in calories from carbohydrate at constant protein content and also increased in response to the increase in calories from protein at constant carbohydrate content. PK activity appeared to be sensitive to dietary carbohydrate, because the activity changed only when diets contained this nutrient and depended on the carbohydrate content in diets. The ratio of PEPCK to PK activity was influenced by both carbohydrate and protein. Whereas there were limits to the extent to which changes in the enzymatic activity can occur in response to the increase in the protein content in diets. Thus, there was an increase in PEPGK activity and a decrease in PK activity in response to the absence or deficiency of carbohydrate in diets. This result was consistent with the concept that mammalian bodies maintain blood glucose by means of changing activities of gluconeogenic and glycolytic enzymes and shifting the direction of the overall metabolite flow through

28) H. A. Krebs and L. V. Eggleston, Biochem. J., 94, 3C (1965).

29) H. Abraham, B. Borrebaek and 1. L. Chaikoff, J. Nutrition, 83, 273 (1964).

30) N. Perez, L. Clark-Turri, E. Rabajille and $H$. Niemeyer, J. Biol. Chem., 239, 2420 (1964). the gluconeogenic or glycolytic system towards glucose formation when supply of exogenous glucose is meager.

The high fat group showed a significant increase in G6Pase activity in comparison with those of the high carbohydrate and the high protein group. The higher response to low content of carbohydrate (below 35\% carbohydrate) in diets at constant protein content and the lower response to the protein content in diets at constant carbohydrate level was observed. In another words, G6Pase activity appeared to respond to the level of fat in addition to a response to the level of carbohydrate in diets and differed from PEPCK activity in respect of the higher response to fat content of diets. The high fat group also caused a marked decrease in GK activity. GK activity showed a progressive increase with increasing the level of carbohydrate in diets at constant protein and when the protein content increased at constant carbohydrate in diets, the higher activity was obtained. Therefore, GK activity also appeared to respond to the level of fat in diets, but the response occurred in opposite direction against that of G6Pase activity, namely, GK activity decreased progressively with increasing the level of fat in diets. The response to the level of fat in diets can be shown more clearly from the ratio of G6Pase to GK activity.

FDPase activity showed an increase with decreasing carbohydrate level in diets, and with increasing protein level in diets. Thus, changes of EDPase activity in response to the level of dietary components were similar to that of PEPCK activity. But a markedly different situation was observed in the case of PFK activity as compared with those of GK and PK. PFK activity of rats fed the diets containing moderate and high levels of carbohydrate tended to decrease as compared with other low carbohydrate groups. Consequently, changes in PFK activity in responce to levels of dietary components occurred in the same direction of those of FDPase acti- 
vity. As a matter of course, the ratio of FDPase to PFK activity was similar among such dietary groups.

As described above, increased activities of G6Pase were observed in rats fed low carbohydrate diets high in fat under conditions of constant protein or constant carbohydrate content. Moreover, in our unpublished data G6Pase activity did not show any changes under the condition of constant fat in diets. No experiment have yet been undertaken which showed influence of the content of dietary fat on gluconeogenic enzymes. Therefore, it should be emphasized to consider that G6Pase activity in rat liver is affected significantly by fat feeding. In addition to the influence of fat content in diets on G6Pase activity, the carbohydrate content in diets had a small but definite influence on the activity because activities of carbohydrate deficient groups were higher than those of groups fed high carbohydrate diets.

These observations were in good agreement with the increased formation of glucose obtained in vitro studies with liver slices as described above. Consequently, the strongest correlation between the capacities of glucose formation by liver slices and gluconeogenic enzyme activities was observed between the rate of incorporation of ${ }^{14} \mathrm{C}$ into glucose by liver slices and G6Pase activity.

The increased formation of glucose from saturating levels of various precursors in slices of rat kidney cortex was also observed by Krebs et al. ${ }^{311}$ and Fuwa et al. ${ }^{321}$ in rats fed high protein diets. In kidney cortex slices,

31) H. A. Krebs, D. A. H. Bennet, D. deGasqust, T. Gascoyne and Y. Yoshida, Biochem. J., 86, 22 (1963).

32) H. Fuwa, Y. Aoyama and T. Yamada, Agr. Biol. Chem., 33, 1464 (1969). the capacity of glucose formation was more significantly influenced by protein content in diets than fat or carbohydrate content in diets. In our previous report, ${ }^{331}$ it was described that changes in G6Pase activity in rat kidney cortex were reflected in the capacity of glucose formation by rat kidney cortex slices, namely, G6Pase activity in rat kidney cortex also increased significantly in rats fed the high protein diet.

It is clear from the above results and discussion that the capacity of glucose formation in liver of rats was changed both by carbohydrate content and by fat content in diets and changes in gluconeogenic capacity with diets were correlated with changes in G6Pase activity. Furthermore, as stated in the introduction, the needs of glucose in mammalian bodies must be met by the conversion of noncarbohydrate precursor to glucose in the body, unless carbohydrate is continually ingested with food, whereby the bodies fed the low carbohydrate diet high in fat may be supplied with glucose by increased capacities of gluconeogenesis in the liver, while the bodies fed the low carbohydrate diet high in protein may be supplied with glucose by those in the kidney.

33) H. Fuwa, H. Suzuki and J. Nagata, Agr. Biol. Chem., 33, 1470 (1969).

The following abbreviations were used in this report: $\mathrm{ATP}=$ adenosine triphosphate; ITP $=$ inosine triphosphate; ADP = adenosine diphosphate; NADP or NADPH $=$ nicotinamide adenine dinucleotide phosphate oxidized or reduced form; OAA=oxaloacetic acid; $\mathrm{PEP}=$ phosphoenolpyruvate; $\mathrm{G} 6 \mathrm{P}=$ glucose 6 -phosphate; $\mathrm{F} 6 \mathrm{P}=$ fructose 6 -phosphate; $\mathrm{FDPase}=$ fructose diphosphatase; G6Pase=glucose 6-phosphatase; PEPCK = phosphoenolpyruvate carboxykinase; $\mathrm{PK}=$ pyruvate kinase; $\mathrm{GK}=$ glucokinase; $\mathrm{PFK}=$ phosphofructokinase $\mathrm{P}_{\mathrm{I}}=$ inorganic phosphate; $\mathrm{GSH}=$ glutathionc, reduced form. 